\title{
Cluster Based Pre-Scaling Up of Improved Irish Potato Variety at Highland Districts of Guji Zone, Southern Oromia, Ethiopia
}

\author{
Korji Dembi*, Kebede Basha, Amare Girma \\ Oromia Agricultural Research Institute (IQQO), Bore Agricultural Research Center, P.O. BOX 21, Bore, Ethiopia.
}

\begin{abstract}
How to cite this paper: Korji Dembi, Kebede Basha, Amare Girma. (2020) Cluster Based Pre-Scaling Up of Improved Irish Potato Variety at Highland Districts of East Guji Zone, Southern Oromia, Ethiopia. International Journal of the Science of Food and Agriculture, 4(3), 323-329.

DOI: $10.26855 /$ ijfsa.2020.09.012
\end{abstract}

Received: August 20, 2020

Accepted: September 15, 2020

Published: September 25, 2020

*Corresponding author: Korji Dembi, Oromia Agricultural Research Institute (IQQO), Bore Agricultural Research Center, P.O. BOX 21, Bore, Ethiopia. Email: korjidembi@gmail.com

\begin{abstract}
Irish potato of Gudane variety was proved to be yielder and disease tolerant than any Irish potato varieties which were demonstrated at the study areas. Therefore, cluster based pre scaling up of Irish potato was conducted at two districts of Guji Zone, Bore and Ana Sora in 2019. The main objective of the study was to promote improved Irish potato variety and thereby increase production and productivity and income of the farmers in the study areas and similar agro-ecologies. One peasant association per district was selected based on their potential to produce Irish potato. FREG approach was followed to implement pre scaling up process. Consequently, 12 farmers of gender inclusive were clustered as FREG at each trial sites owing three hectares of land, each farmer contributing 0.25 hectare. In total, 24 farmers (17 male \& 7 female were benefited scaling up). Training was given for farmers, Development agents, subject matter specialists and different stakeholders. Recommended seed and fertilizer rates, row between space and plant were used with all management practices. Diffused Light Storages were constructed at both study sites. Joint monitoring and evaluation were organized and undertaken. Field day was also organized on which different stakeholders participated and experience shared. Quantitative data such as yield were collected and analysed using SPSS whereas farmers' feedback were analysed qualitatively. A mean yield of 14.9 tons ha ${ }^{-1}$ obtained. The technology has paramount importance in improving livelihood of farmers as more yield could be harvested. Hence, Bureaus of Agriculture and Natural Resource of respective districts should hand over to sustain the technology and reach more number of farmers over wider geographical areas of similar agro ecologies. Securing agro chemicals in advance, early planting and construction of Diffused Light Storage are highly recommended.
\end{abstract}

\section{Keywords}

Cluster based pre scaling up, Diffused Light Storage, FREG approach, Gudane variety

\section{Introduction}

Root and tuber crops are one of the most efficient crops in converting natural resource, labor and capital into a high quality food with wide consumer acceptance [1]. The food potential of root and tuber crops has not yet been fully exploited and utilized despite their substantial contributions towards food security, income generation, provision of food energy and resource base conservation [2]. Potato has high potential for improving food security, increasing household 
income and poverty reduction and also provides important nutrients. Potato tubers are an excellent food source for providing energy from carbohydrates, but are also rich in minerals and vitamins, especially vitamin $\mathrm{C}$ and present significant amounts of quality protein [3, 4].

In Africa, the area under potato production is about 1.5 million hectares with an average yield of 10.8 tons ha-1 $[3]$. As stated by Kolech et al. [5], potato is considered as a food security crop that helps to meet the increasing food demands in the tropical highlands of Sub-Saharan Africa. Potato has short cropping cycle and higher production per hectare per day when compared to other arable crops [6]; therefore, it provides hope for improving the lives of lots of small holder farmers in the risk-prone highlands. Root crops are good sources of food, cash and foreign exchange for the majority of smallholder farmers in Ethiopia [3]. It has a promising prospect in improving the quality of the basic diet in both rural and urban areas of the country. Certainly, potato is the only food crop grown to any large extent in the dry season where rain-fall is erratic and unpredictable in the months of March through May [7].

Among African countries, Ethiopia has the most potential of potato production because about $70 \%$ of the available agricultural land is suitable for potato production which is located at an altitude of 1,500 to 3,000 m.a.s.l with an annual rainfall between 600 and 1,200 mm [8, 9]. Among root and tuber crops in Ethiopia, potato ranks first in volume production and consumption followed by cassava, sweet potato and yam [10,11]. The major limiting factors to potato productivity in Ethiopia include lack of high yielding varieties, diseases, post-harvest losses due to poor handling and storage facilities, insufficient clean potato seed tubers, poor seed distribution system, and inadequate production technologies [12].

In the highland districts of Guji Zone, Irish Potato is one of the most important root and tuber crops produced on spring (belg) and autumn (meher), Ethiopian production seasons and mainly in spring season. Irish Potato is produced mainly as cash crop and in some extent as food crop by farmers in the highland areas. Regardless of its role in the farming system and in supporting the national economy, yield has been low and stagnant for several years due to different factors. These factors include lack of high yielding varieties tolerant to Late Blight, poor soil fertility, climatic limitation, inadequate seeds, lack of appropriate cultural practices, poor post-harvest management \& storage problems, high cost of farm inputs, diseases and insect pests [13], particularly limited production and distribution of improved seed among resource poor farmers. In addition to this, the access of the improved varieties has been low for poorest segment of farmers. The study areas are potential for potato production despite the prevalence of stated production constraints. In relation to this, there is high need of improved technologies of this crop by farmers that can enable them to improve their income through increased production and productivity. Gudane variety was proved to have potential for up scaling to improve productivity, food and nutrition security, and climate resilience of resource poor farmers during adaptation and demonstration by Bore Agricultural Research Centre at some highland parts of the study areas. Therefore, cluster based pre scaling up of improved potato technology would help to enhance production and productivity of the crop for better livelihood, improvement of food security and self sufficiency of small scale farmers in the study areas.

\section{General Objective:}

$\checkmark$ To promote improved Irish potato variety and thereby increase production and productivity and income of the farmers in the study areas and similar agro-ecologies.

\section{Specific Objectives:}

The specific objectives of the study were to:

$\checkmark$ Create wider demand pull by reaching large number of users over relatively wider geographical areas;

$\checkmark$ Increase farmers' income and livelihood;

$\checkmark$ Increase local capacity for future scaling up of the technology.

\section{Materials and Methods}

\subsection{Description of the Study Areas}

The study was conducted in selected highland districts of Guji Zone. Bore and Ana Sora were the two districts selected for this study among the highland districts in the Guji Zone. The districts are characterized by two agro climatic zones, namely humid which starts in early April up to October and sub humid which starts late November up to beginning of March. The major soils of the two districts are Nitosols (red basaltic soils) and Orthic Acrosols. The two soils are found on the highland areas, and they are red brown and black brown in colors and on sloping topography and their utilization are good under natural vegetation. The farmers of these districts produce cereals such as wheat, barley and maize, pulses such as faba bean and pea, tubers like Irish Potato and others such as fruits and vegetables.

\section{Bore District}

Bore district is placed at a distance of $385 \mathrm{~km}$ from Finfinne, capital city of Ethiopia and $205 \mathrm{~km}$ from Negele, thecapital town of Guji Zone. Geographically, Bore district is at the Northern part of Guji Zone. While astronomically situated between $5^{\circ} 57^{\prime} 23^{\prime \prime}-6^{\circ} 26^{\prime} 52^{\prime \prime}$ northing latitudes and $38^{\circ} 25^{\prime} 51^{\prime \prime}-38^{\circ} 56^{\prime} 21^{\prime \prime}$ easting longitudes. Most of the earth 
surface of the district has an undulating land surface with an elevation ranging from 1,450-2,900 meters above sea level. It has the annual rain fall of $1,250 \mathrm{~mm}$ and the annual temperature ranges from $15-24{ }^{\circ} \mathrm{C}$.

\section{Ana Sora District}

It is situated at a distance of $410 \mathrm{~km}$ from Finfinne and $180 \mathrm{~km}$ from Negelle. Astronomically, the district is located between $6^{\circ} 20^{\prime} 30^{\prime \prime}-5^{\circ} 57^{\prime} 30^{\prime \prime}$ northing latitudes and $38^{\circ} 39^{\prime} 30^{\prime \prime}-38^{\circ} 57^{\prime} 30^{\prime \prime}$ easting longitudes. It is most humid and sub humid moisture condition, which has relatively longer growing season. It comprises the annual rain fall of 1,750 mm and mean temperature of $17.5-28^{\circ} \mathrm{C}$.

\subsection{Approaches to the Cluster Based Pre-Scaling Up Activity}

Technically, pre-scaling up activities is headed by demonstration and participatory variety selection with farmers and pertinent stakeholders. Hence, in the recent years, the potato technologies were demonstrated on some farmers at the respective sites where the technology was intended to be pre scaled up. Results from the evaluation process revealed that Gudane variety had met the farmers' requirement that paved the way to this activity. It was based on this result that the cluster based pre scaling up phase was planned and executed using extension approaches.

For the sake of enhancing efficiency and effectiveness, integration and cooperation with stakeholders implemented for the achievements of the strategy. Accordingly: Organizing stakeholder forum for discussion with responsible and cooperative participants at district level to have a common understanding of this activity, signing memorandum of understanding, appointing focal persons and establishing Farmers Research Extension Groups (FREGs) at each kebele were done successfully. Trainings on capacity building regarding knowledge, skill and attitude of potato production, management and package, construction of Diffused Light Storage, concept of cluster, economic valuation of potato, FREG approach and seed dissemination mechanism was delivered for farmers, agricultural experts at district level and development agents (DAs)by multidisciplinary team organized from Bore Agricultural Research Center (BoARC), distribution of potato technology (Gudane) with its recommended packages and other agricultural inputs (agro-chemicals) to participating farmers. FREG member farmers and other follower farmers were encouraged to participate in the physical activities from the beginning up to the end. Joint monitoring and evaluation like regular field visit by extension agents and extension counterparts, joint field visit and supervision at different crop stage, field day organized, discussion session and result communication forum were also structured. Seed delivery mechanisms like convincing the host farmers to appreciate farmer-to-farmer seed exchange mechanism with an optimum price at the end of the activity life span facilitated.

\subsection{Stakeholder Analysis}

In enhancing potato technologies generation, dissemination, improving Irish Potato production and productivity, Bore Agricultural Research Centre was closely working and has made frequent consultation with its respective stakeholders. Pre-scaling up activity should be done by different actors in partnership and collaborative approach. So stakeholder analysis is highly important for institutional arrangement to share roles and responsibilities before embarking on the pre-scaling up activity. Thus, stakeholder analysis was undertaken to identify potential stakeholders. Points such as: Who are the stakeholders? How big is their stake? How much they are closer to the project? What are their roles, duties and responsibilities in implementing the activity? How does the collaboration support the opportunities to bring the required impact? And finally the roles, duties and responsibilities of each actor were clearly stated in implementing the activity. To this end, zonal and district agricultural experts, district cooperatives, Development Agents and Researchers were the identified stakeholders (Table 1).

\subsection{Sites and Farmers Selection Procedure}

Selection of the districts was accomplished by a multi-disciplinary team from Bore Agricultural Research Centre using self-experience gained during potato demonstration activity in the recent years and collaboration with experts of the respective districts. Accessibility and potentiality, convenience of the areas to the technology and representativeness of the trial fields in terms of location and suitability for more farmers to visit the field, were the most important criteria to select both the districts and the peasant associations under consideration.

As Development Agents are nearer to and information rich about the farmers in their respective locality, they were entirely given the work of farmers selection based on the criteria set by researchers. On top of this, having appropriate and sufficient plots, good history of managing experimental or non-experimental plots were the other criteria used to select the participating farmers. Accordingly, from each peasant associations one FREG which comprises 12 clustered farmers was nominated based on their consent to work in group and provide three hectares of land per cluster. The clustered FREG member farmers were re-clustered in to three sub groups comprising of four farmers with one hectare of land. Consequently, a total of 24 hosting farmers as FREG were organized, under which other farmers were organized as follower farmers to share knowledge, skill and experience for further promotion mechanism. 
Table 1. Roles and responsibilities Stakeholders and hosting FREG member farmers in implementing the activity

\begin{tabular}{|c|c|c|}
\hline No & Stakeholders & Roles and responsibility \\
\hline 1 & $\begin{array}{l}\text { Bore Agricultural } \\
\text { Research Centre }\end{array}$ & $\begin{array}{ll}> & \text { Coordination and facilitation } \\
> & \text { Provision of potato technologies } \\
> & \text { Provision of training } \\
> & \text { Technical backstopping } \\
> & \text { Organize field days and } \\
> & \text { Supervision and joint monitoring and evaluation with zone and district Bureau of agri- } \\
\text { cultural and Natural resource }\end{array}$ \\
\hline 2 & $\begin{array}{l}\text { Agriculture and Natural } \\
\text { resource Office (at Zone, } \\
\text { district and Kebele level) }\end{array}$ & $\begin{array}{ll}> & \text { Assist in site and participant farmers selection } \\
> & \text { Follow up day to day activities from zone to Kebele level } \\
> & \text { Assist in providing training } \\
> & \text { Facilitate seed distribution } \\
> & \text { Jointly organize and participate on field days }\end{array}$ \\
\hline 3 & FREG member farmers & $\begin{array}{l}>\quad \text { Allocate land and perform required agronomic practices } \\
>\quad \text { Actively participate in the training for capacity building } \\
>\quad \text { Share skills and experiences to neighbor farmers } \\
>\quad \text { Transfer produced seed to surrounding farmers and } \\
>\quad \text { Finally, supply excess produced seed to cooperatives }\end{array}$ \\
\hline 4 & Cooperative & $\begin{array}{ll}> & \text { Agricultural input supply } \\
> & \text { Facilitate Potato seed marketing }\end{array}$ \\
\hline
\end{tabular}

\subsection{Planting Materials and Agronomic Practices}

Gudane, Irish potato variety that were recently adapted and demonstrated at Bore Agricultural Research Centre were pre-scaled up at 24 clustered farmers' field. The seed rate was 1.8 tons ha ${ }^{-1}$ with a spacing between rows $75 \mathrm{~cm}$ and between plants $25 \mathrm{~cm}$. So that 10.8 tons of improved Gudane of this variety were delivered for a total of six hectares of land and for 24 FREG farmers at both trial sites. $100 \mathrm{Kg} \mathrm{ha}^{-1}$ Urea (50 Kg at planting time and $50 \mathrm{Kg}$ during earthing up) and $200 \mathrm{Kg} \mathrm{ha}^{-1} \mathrm{NPS}$ was applied at planting time. All the management practices such as land preparation and weeding were applied as per the recommended for Irish potato production. All farm operations such as land preparation, land levelling, planting, weeding, harvesting, and construction of Diffused Light Storage for potato storage were carried out by FREG member farmers with close assistance and supervision of concerned participating institutions (Research Centre and Agriculture and Natural Resource Office). INDOFIL M-45, a preventive fungicide used for the control of Late Blight in potato was also sprayed at the rate of $2.2 \mathrm{Kg} \mathrm{ha}^{-1}$ in 750 litres of water and the application was repeated once at fortnight interval, Farmers' full participation at all stages of the activity was maintained during the implementation period.

\subsection{Joint Monitoring and Evaluation}

From beginning of site selection until harvesting, frequent visits to farmers, monitoring and provision of technical advice, follow up actions were designed based on emerging knowledge, skill and technical needs. Researchers, extension agents, experts and farmers were jointly participated on continues supervision of the experiment.

\subsection{Technology Dissemination Methods}

Appropriate extension approaches and all extension teaching methods were employed during the implementation of the cluster based pre-scaling up activity.

$>$ Telephone call

$>$ Field visit and supervision

$>$ Field day

$>$ Method demonstration (to impart the skills) and result demonstration (to show the performance)

$>$ Group meeting and discussion

$>$ Training (both theoretical and practical)

$>$ Mass media (OBN Television)

> Print Media (leaflets, brochures posters) were used for creating awareness, enhancing clients' knowledge and skill, changing attitude on using fully recommended packages of improved potato technology and the importance of farmer-to-farmer variety dissemination across similar agro-ecologies. 


\subsection{Method of Data Collection and Analysis}

Data such as total amounts of inputs distributed for participant farmers, total number of farmers participated in the training and field day by gender, role of farmers and other stakeholders in technology dissemination, yield data, income from adoption of technology, impact in livelihood due to adoption of the technology and farmers perception were collected using checklists through interview and discussions. The collected data were entered into SPSS and analysed using simple descriptive statistics and narrating the qualitative explanation of the farmers.

\section{Results and Discussion}

\subsection{Yield Performance}

In spite of the inevitable variability in performance between and even within clustered locations, yield performance of the potato variety was promising, though by far less than the potential yield it could give. The variability in yield performance might have stemmed from difference in land preparation in the recommended extent, as farmers of the areas normally lagged behind in early preparing their land, they preferred the usual way of preparing their land, for the sake of their livestock to graze on it, the status of soil fertility, difference in management and rust out break during flowering stage and others. Despite this fact, a mean yield of 14.9 tons ha ${ }^{-1}$ was obtained (Table 2).

Table 2. Potato yield obtained across districts

\begin{tabular}{|c|c|c|c|c|c|c|}
\hline \multirow{3}{*}{$\begin{array}{c}\text { No } \\
1\end{array}$} & \multirow{3}{*}{$\begin{array}{c}\text { Districts } \\
\text { Cluster at Bore district }\end{array}$} & \multicolumn{3}{|c|}{ Yield across sub- clusters( tonsha $^{-1}$ ) } & \multirow{3}{*}{$\begin{array}{l}\text { Total } \\
44.3\end{array}$} & \multirow{3}{*}{$\begin{array}{r}\text { Mean } \\
14.8 \\
\end{array}$} \\
\hline & & Sub-cluster one & Sub-cluster two & Sub-cluster three & & \\
\hline & & 17.0 & 15.0 & 12.3 & & \\
\hline \multirow[t]{2}{*}{2} & Cluster at Ana Sora district & 16.0 & 14.7 & 14.3 & 45.0 & 15.0 \\
\hline & Total & 33.0 & 29.7 & 26.6 & 89.3 & 14.9 \\
\hline
\end{tabular}

\subsection{Capacity Building and Knowledge Sharing}

Before the beginning of the cluster based pre scaling up activity, comprehensive trainings were given. In this regard, training on knowledge, skill and attitude were the main approaches that used to create awareness about improved potato technologies among farmers, to capacitate the farmers' and others' knowledge and skill about potato and management packages. To this end, multidisciplinary team were organized to deliver the training in capacity building and facilitating extension efforts of potato technologies. The team was composed of socio-economist, research-extensionist, breeder, pathologist, agronomist and weed scientist from Bore Agricultural Research Centre.

A total of 100 farmers (70\% male and 30\% female) from the two districts of which 24 FREG member farmers, 12 DAs, 9 subject matter specialists (SMS), 2 experts from union and 2 experts from cooperative office at Bore and Ana Sora districts were participated on both theoretical and on-spot training on potato production and management packages (Table 3). Particularly, the trainings were focused on available improved potato production technologies (varieties, agronomic recommendations and packages, etc.); input utilization; weeds, diseases like Late Blight and their controlling ways; agrochemicals applications and safety precautions and; the importance of crop rotation to break mono cropping problem, the concept of FREG approaches and quality seed production techniques and post-harvest handling andknowledge and skill of Diffused Light Storage construction. The training materials were printed and dispersed to the agricultural experts and development agents.

Table 3. Summary of potato training participants

\begin{tabular}{|c|c|c|c|c|c|c|c|c|}
\hline \multirow{5}{*}{$\begin{array}{l}\text { Year } \\
2019\end{array}$} & \multirow{3}{*}{$\begin{array}{l}\text { AGP- II Dis- } \\
\text { tricts }\end{array}$} & \multicolumn{6}{|c|}{ Participants } & \multirow{3}{*}{ Tota } \\
\hline & & \multicolumn{3}{|c|}{ Farmers } & \multicolumn{3}{|c|}{ DAs and experts } & \\
\hline & & Male & Female & Total & Das & Experts & Total & \\
\hline & Bore & 35 & 15 & 50 & 6 & 7 & 13 & 63 \\
\hline & Ana Sora & 35 & 15 & 50 & 6 & 6 & 12 & 62 \\
\hline & Total & 70 & 30 & 100 & 12 & 13 & 25 & 125 \\
\hline
\end{tabular}

\subsection{Input Distribution}

All the necessary inputs like seeds and fertilizers were distributed for the host farmers. Anti-rust chemical was also distributed and sprayed. During the course of cluster based pre scaling up process, a total of 24 farmers (17 male and 7 women) were directly reached. Total number of farmers reached, area covered and amount of inputs distributed were 
indicated in the Table 4.

Table 4. No of beneficiary farmers, area covered in hectare and input distributed

\begin{tabular}{|c|c|c|c|c|c|c|c|c|}
\hline \multirow{3}{*}{$\begin{array}{l}\text { AGP-II Dis- } \\
\text { tricts }\end{array}$} & \multirow{3}{*}{$\begin{array}{l}\text { Area covered } \\
\text { (hectare) }\end{array}$} & \multirow{2}{*}{\multicolumn{3}{|c|}{ No of farmers }} & \multicolumn{4}{|c|}{ Amount of inputs distributed } \\
\hline & & & & & \multirow[t]{2}{*}{$\begin{array}{l}\text { Potato Seed of Gudane } \\
\text { variety (in tons) }\end{array}$} & \multirow[t]{2}{*}{$\begin{array}{l}\text { INDOFIL M- } 45 \\
\text { (in Kg) }\end{array}$} & \multicolumn{2}{|c|}{$\begin{array}{l}\text { Fertilizers incurred by farm- } \\
\text { ers (in quintals) }\end{array}$} \\
\hline & & Male & Female & Total & & & NPS & UREA \\
\hline Bore & 3 & 8 & 4 & 12 & 5.4 & 13.2 & 6 & 3 \\
\hline Ana Sora & 3 & 9 & 3 & 12 & 5.4 & 13.2 & 6 & 3 \\
\hline Total & 6 & 17 & 7 & 24 & 10.8 & 26.4 & 12 & 6 \\
\hline
\end{tabular}

\subsection{Field Day}

Field day is one of the extension services and methods used to transmit information and creation awareness for larger audience and on which bad and good events evaluated. Field day can be organized at different stages in crop production systems. It can be two or three times on which the stages are at vegetative, flowering and maturity depending on crop type and nature produced.

Field day is used as tool to address large number of farmers, even invited farmers who did not produce improved potato to create massive awareness and large impacts on technologies for further production and scale up on farmers field. Not only farmers but also other stakeholders were also invited to participate on the event. In addition, during field day mass extension methods like leaflets, banner and Television were used to reach large audience.

Consequently, a total of 70 farmers (22 women), 14 development agents and 15 experts and 38 other stakeholders were participated on the occasion. Besides, information on the field day was propagated by Oromia Broadcasting Network to disseminate information for wider community. A total of 120 leaflets were distributed for the participants which describes the production, agronomic practices and overall managements of improved potato. Finally, at the end of visit during field day, group discussion was conducted to grasp farmers' feedback on strength and weakness of improved potato variety. Besides, constraints in agricultural production in general and potato Late Blight in particular; needs and interests of farmers on other improved varieties were points raised by participants on the program.

\subsection{Farmers' Feedback}

During the course of the cluster based pre-scaling up process and at the final stage of the activity, an assessment was made to know how the farmers perceived the technology. Result of the assessment revealed that potato technology liked by farmers as the productivity of potato from small unit areas of land was proved to be very vast when compared to other crop technologies. Moreover, the technology had also premium price at the peak time when stored in Diffused Light Storage and sold in the form of seed. The other attributes of this technology is that it is sown at the early stage of the main cropping season and harvested after 90-120 days. This provides farmers with the advantage of engaging in double cropping. This allows more intensive and productive use of land that in turn increases the income and livelihood of farmers. The issue of agro-chemicals for potato fungus was frequently raised by the farmers.

\subsection{Economic Return to Farmers}

Farmers of the study areas benefited from this cluster based pre scaling up process in multi dimensions; clustered FREG member farmers obtained potato seed of 10.8 tons and 26.4 Kg of INDOFIL M-45, fungicide chemical for free. This evaded the burden of suffering inputs which could have cost them about 21,600 and 4,160 ETB ha ${ }^{-1}$ for incurring seed and chemical even though fertilizers cost $\left(4,500\right.$ ETB ha $\left.{ }^{-1}\right)$ burdened to FREG member farmers to insure sense of ownership to the project. Moreover, every management activities starting from the very beginning to the end of project life span was performed by the cooperation of clustered farmers themselves and expenses for wage was minimized. Diffused Light Storage were built at each trail sites (standard storage at Bore, Abayi Kuture peasant association and from locally available materials at Ana Sora, Raya Boda peasant association) and potato tubers were stored and geminated at each trial sites to ensure seed availability. So that follow farmers and other farmers from similar agro ecologies could accessed to available potato technology at their vicinity with very minimal transaction cost. FREG member farmers produced an average yield of 14.9 tons $\mathrm{ha}^{-1}$. This indicated that FREG member farmers earned the average net profit of 174,300 ETB ha ${ }^{-1}$. This could contribute a lot to ensure food security and improve livelihood of farmers.

\section{Conclusions and Implications}

The activity was supplementary to the methods that the research system follows in its technology transfer via re- 
search-extension linkage. Along with the option of improved technology transfer to access limited areas, the approach has served to activate the local formal and informal seed systems. Because the cluster based pre scaling up was intended that the produced seed would reach other farmers at similar agro ecologies. This improved access to the technology used in the intervention. The linkage created among the different stakeholders assured the use of seed produced for the intended purpose.

The technology is very important in improving livelihood of farmers in the study areas as it gave vast tuber yield and benefit from small unit areas of lands given that the use of full production package. This alleviates the food security problems and ensures availability of potato seed from which farmers of the study areas suffer, only if stored in Diffused Light Storage, otherwise securing potato seed in the study areas is continued to be a major problem. Early planting during the beginning of rain at the main cropping season, particularly in March, minimizes the problem of mono cropping and Late Blight in potato. The activity was completed, and the extension division of the centre does not disseminate the technology further than this boundary. Therefore, the technology should be handed over to the respective Bureaus of Agriculture and Natural Resource of Bore and Ana Sora districts for further promotion and reach more number of farmers over wider geographical areas of similar agro ecologies. Other local organizations mainly focus on seed sectorsuch as unions, NGOs and farmers' cooperative should further promote and scale up the technology in reducing quality seed problem and boost the economy by reducing poverty and addressing food insecurity problem of the country in general and study areas in particular. Securing agro chemicals in advance and early planting is highly recommended to escape from potato disease. Potato farmers should also give due emphasis to construct Diffused Light Storage at least from locally available materials depending on their economy.

\section{Acknowledgement}

The authors would like to gratitude Agricultural Growth Program (AGP II) and Oromia Agricultural Research Institute (IQQO) for financially supporting this research work. The staff of Bureau of Agriculture and Natural Resource of Bore and Anna Sorra districts where the study conducted, and 24 clustered FREG household farmers for hosting and implementing the research activities to knockout the intended objectives.

\section{References}

[1] Horton, D. (1980). The potato as a food crop in the developing countries. A Bulletin of the International Potato Centre, Lima, Peru, p. 30.

[2] Tesfaye, A., Kiflu, B., Chilot, Y., and Gebremedhin, W. G. (2008). Socioeconomics and technology transfer. In: Root and tuber crops: the untapped resources, Gebremedhin W. G. Endale G. and Berga L. (Eds.). EIAR, Addis Ababa. Pp. 131-152.

[3] FAOSTAT. (2008). Country Profile on potato production and utilization: Ethiopia.

[4] Berga Lemaga, R. Kakuhenzire, Bekele Kassa, P. T. Ewell, and S. Priou. (2005). Integrated control of potato bacterial wilt in Eastern Africa: The experience of African Highlands Initiative. Pp. 145-158. In: Bacterial Wilt Disease and the Ralstonia Solanacearum Species Complex. (Eds.) C. Allen, P. Prior and A. C. Hayward, APS Press, St. Paul, Minnesota USA, P. 510.

[5] Kolech, Semagn Asredie, Walter De Jong, Donald Halseth and Steffen Schulz. (2019). Understanding farmer needs and unlocking local genetic resources for potato improvement: a case study in Ethiopia. Afr. J. Food Agric. Nutr. Dev.; 19(1): 13883-13905.

[6] FAO. (2009). New light on a hidden treasure, Food and Agriculture Organization, Rome, p. 136.

[7] Kolech S. A., Halseth D., De Jong W., Perry K., Wolfe D., Tiruneh F. M. and Schulz S. (2015). Potato Variety Diversity, Determinants and Implications for Potato Breeding Strategy in Ethiopia. American Journal of Potato Research 92 (5): 551-566.

[8] Ministry of Agriculture and Rural Development. (2010). Crop variety register. Crop development department. Addis Ababa, Ethiopia.

[9] Egata Shunka Tolessa. (2019). A review on water and nitrogen use efficiency of potato (Solanum tuberosum L.) in relation to its yield and yield components. Archives of Agriculture and Environmental Science, 4(2): 119-132.

[10] CSA (Central statistical agency). (2016). Agricultural sample survey, report on area, production and farm management practice of belg season crops for private peasant holdings. Volume V, Statistical Bulletin 578. Addis Ababa, Ethiopia.

[11] Struik P. C., Wiersema S. G. (1999). Seed potato technology. Wageningen University Press.

[12] Hipha A., Meuwissen M. P. M., Tesfaye A., Lommen W. J. M., Lansink A. O., et al. (2010). Analysis of seed potato systems in Ethiopia. American Potato Journal, 87: 537-552.

[13] Abebe Chindi, Gebremedhin W/Giorgis, Atsede Solomon, Lemma Tessama, and Kassaye Negash. (2014). Rapid Multiplication Techniques (RMTs): A Tool for the Production of Quality Seed Potato (Solanum tuberosum L.) in Ethiopia. Asian Journal of Crop Sciences, 6(3): 176-185, 2014. 